\title{
Sensors for observing ecosystem status
}

\author{
S. Kröger, E. R. Parker, J. D. Metcalfe, N. Greenwood, R. M. Forster, D. B. Sivyer, and D. J. Pearce \\ Centre for Environment, Fisheries and Aquaculture Science (Cefas), Pakefield Rd, Lowestoft, Suffolk NR33 0HT, UK
}

Received: 12 March 2009 - Published in Ocean Sci. Discuss.: 23 April 2009

Revised: 9 September 2009 - Accepted: 2 October 2009 - Published: 4 November 2009

\begin{abstract}
This paper aims to review the availability and application of sensors for observing marine ecosystem status. It gives a broad overview of important ecosystem variables to be investigated, such as biogeochemical cycles, primary and secondary production, species distribution, animal movements, habitats and pollutants. Some relevant legislative drivers are listed, as they provide one context in which ecosystem studies are undertaken. In addition to literature cited within the text the paper contains some useful web links to assist the reader in making an informed instrument choice, as the authors feel that the topic is so broad, it is impossible to discuss all relevant systems or to provide appropriate detail for those discussed. It is therefore an introduction to how and why ecosystem status is currently observed, what variables are quantified, from what platforms, using remote sensing or in-situ measurements, and gives examples of useful sensor based tools. Starting with those presently available, to those under development and also highlighting sensors not yet realised but desirable for future studies.
\end{abstract}

\section{Introduction}

Over recent years a shift in emphasis has occurred in marine monitoring and management away from looking at isolated individual components and towards assessments of ecosystem health and elucidating connections between different ecosystem components. This has involved the development of the "ecosystem approach to the management of human activities" (see for example records of the joint meeting of the Helsinki \& OSPAR Commissions, 2003) and a call for more cross-boundary, multi-disciplinary approaches to understanding the impact that humans have on the seas. This

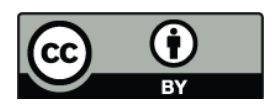

Correspondence to: S. Kröger (silke.kroeger@cefas.co.uk) is both reflected in, and a reflection of the legislative drivers (European Directives) as summarised in Table 1. The most recent wide-reaching directive is the European Marine Strategy Framework Directive (which came into force on the 15 July 2008), a thematic strategy for the protection and conservation of the marine environment. The individual Marine Strategies required under this directive will contain a detailed assessment of the state of the environment, a definition of "good environmental status" (GES) at regional level and the establishment of clear environmental targets and monitoring programmes. Seabed integrity and habitats are key themes of GES supported by the development of indicators (Rees, 2003); (Hiscock et al., 2004; Rogers and Greenaway, 2005). It is envisaged that each Member State will draw up a programme of measures, where impact assessments, including a detailed cost-benefit analysis will be required prior to introduction. (http://ec.europa.eu/environment/water/marine/ index_en.htm).

To assess the impacts of different activities, such as fishing, disposal of waste, nutrient inputs, and aggregate extraction, it is not sufficient to look at them individually, without also trying to understand where effects might be cumulative. In addition one has to include other pressures such as climate change and how they will modulate the ecosystem response to any other anthropogenic impact. A schematic overview of the marine ecosystem is given in Fig. 1. Processes such as nutrient and carbon cycling, energy transfer from prey to predator, and transfer of excreted or dead material link the individual components in a complex interconnected network. Quantification of these processes and controlling factors is therefore crucial to understanding and managing ecosystem function.

When discussing sensors that are relevant to the observation of ecosystem status, a useful starting point is the other white papers published following the international OceanSensors workshop in 2008 and published in the special issue Ocean sensors (Editors: T. Dickey, R. Prien, and

Published by Copernicus Publications on behalf of the European Geosciences Union. 


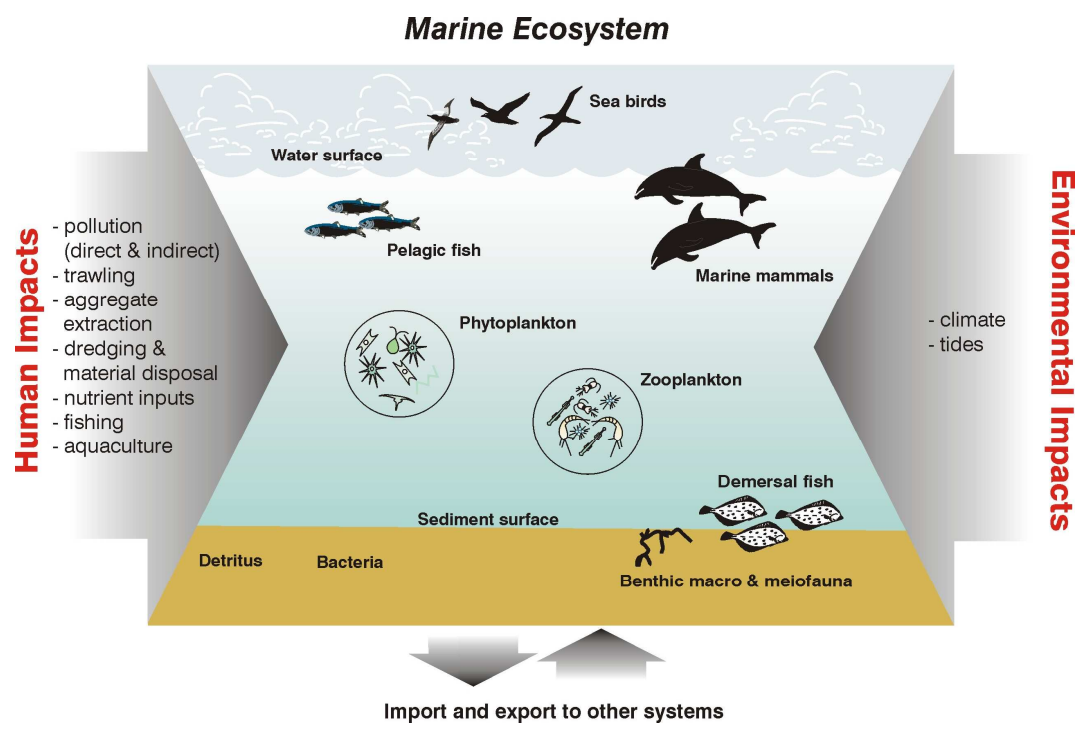

Fig. 1. Schematic representation of the marine ecosystem (from Kröger and Law, 2005a).

Table 1. Legislative drivers for marine observations.

\begin{tabular}{ll}
\hline Directive & Reference \\
\hline Bathing Waters Directive & $76 / 160 / \mathrm{EEC}$ \\
Birds Directive & $79 / 409 / \mathrm{EEC}$ \\
Environmental Impacts & $85 / 337$ as \\
Assessment Directive & amended by $97 / 11$ \\
Urban Waste Water Treatment Directive & $91 / 271 / \mathrm{EEC}$ \\
Nitrates Directive & $91 / 676 / \mathrm{EEC}$ \\
Habitats Directive & $92 / 43 / \mathrm{EEC}$ \\
Integrated Pollution Prevention & $96 / 61 / \mathrm{EEC}$ \\
and Control Directive & \\
Water Framework Directive & 2000/60/EC \\
Marine Strategy Framework Directive & 2008/56/EC \\
\hline
\end{tabular}

G. Griffiths), as many different types and classes of sensors will yield relevant information - be it sensors looking at nutrients or hazards, sensors using molecular biology or detecting ocean carbon, sensors used in-situ on autonomous platforms or those making remote measurements from space. The relevant time scales range from seconds to years and the space scales from nanometers to thousands of kilometres, as illustrated by T. Dickey (Dickey, 1990). Therefore many different observational strategies have to be used to address them and Fig. 2 gives an overview of such marine observational strategies. Each of the described observational platforms can be equipped with a range of sensors, and increasingly "ships of opportunity" add valuable spatial coverage to that obtained with dedicated RVs (Harashima et al., 2006; Urban et al., 2008).
The key to making any particular sensor a tool for observing, ecosystem status, is the way in which the sensor output is used in the context of other measurements, to build up the bigger picture. A range of international programmes exists to integrate activities. For example, the Global Ocean Observing System (GOOS) is an international programme preparing the permanent global framework of observations, modelling and analysis of ocean variables needed to support operational ocean services wherever they are undertaken around the world. EuroGOOS (http://www.eurogoos.org/) is an Association of Agencies, founded in 1994, to further the goals of GOOS, and in particular the development of Operational Oceanography in the European Sea areas and adjacent oceans.

Many different methodologies exist by which to group or classify sensors, for example by target group (i.e. physical, chemical or biological sensor), by transduction mechanism (optical, acoustical, electrochemical etc.) or sample matrix (air, water, sediment), and each of these classifications have merit. When selecting specific examples of sensors for ecosystem status, it was considered a good start to look at measurement methods that inform us about biogeochemical cycles and primary productivity, as the carbon assimilation by bacteria, plankton and seaweeds form the basis of the foodchain and as such determine overall marine productivity. Ideally one would like to know not only how much production occurs, but also by whom - i.e. identify the species of primary producers and what diversity is present. The next steps are measurements that look into secondary production, such as grazing of plankton by copepods or other invertebrates, and transfer of nutrients throughout all trophic levels. While various sensors exist to look at phytoplankton, the higher trophic levels are less easy to quantify with sensors. 


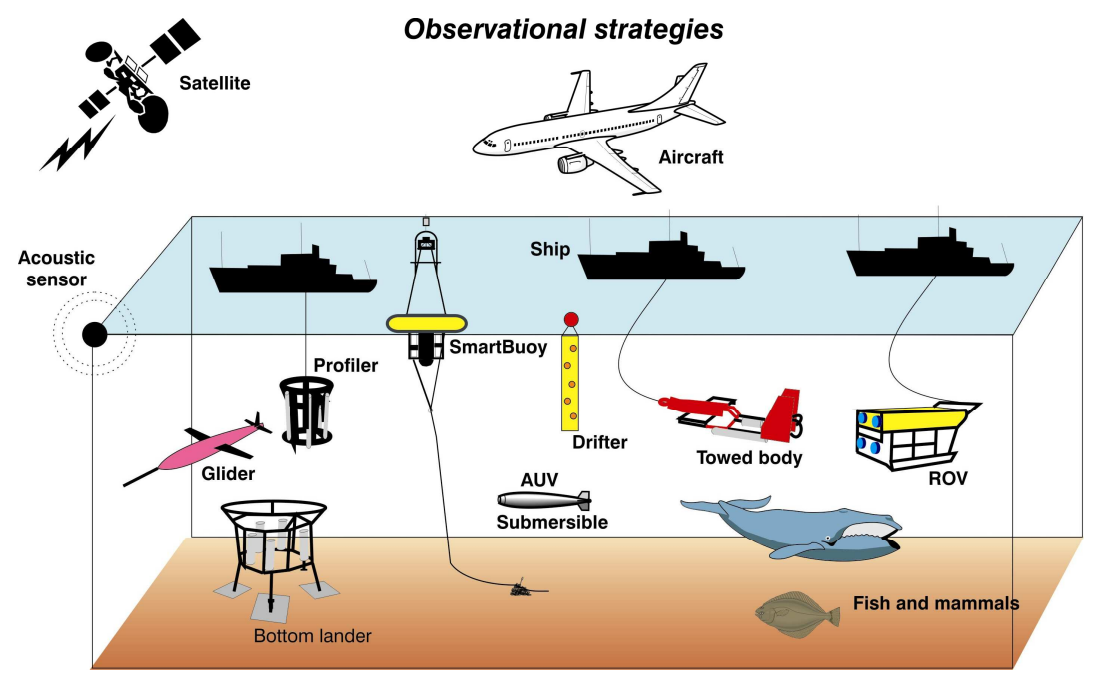

Fig. 2. Schematic overview of marine observational strategies (from Kröger and Law, 2005a). AUV: automonous underwater vehicle; ROV: remotely-operated vehicle.

Still, some devices can be useful in assessing these ecosystem components and their interactions, such as those discussed under speciation, animal movements or habitat classification.

The big issue for most monitoring programmes is the anthropogenic impact on ecosystem status. Information relevant to this is obtained from sensors that measure a human activity or pressure directly, for example sensors for quantifying chemical pollution or nutrient inputs. Next, the correlation of the impact with a change in the ecosystem "state" has to be evaluated - for example by measuring increased primary production, shifts in species composition, decreases in oxygenation, or occurrence of disease in animals following pollution events (ecotoxicology). To understand ecosystem processes, we have to be able to understand and quantify the cycles of carbon, nutrients and oxygen mediated by biotic and abiotic processes and how our activities modulate these flows. Obviously impact assessments are not limited to anthropogenic impacts, but also cover natural events and the line between these two may be fluid. When are shifting ocean currents and associated shifts in salinity, temperature, nutrient concentration etc. human induced, for example as a consequence of global warming, and when are they down to natural cycles and dynamics?

Sensors can play an important role in answering the questions about current state as well as rate and direction of change, thus providing the evidence on which to base any management action, and in the section below some specific examples of relevant sensors will be described.

\section{Review of state-of-technology}

The wide-ranging nature of this chapter will make it impossible to be exhaustive in describing sensors in use or potentially useful. The reader is also referred to additional material listed in tables, in the bibliography and under useful web links, even if no further description of the corresponding device is made in the text.

\subsection{Remote sensing}

To start with some general definitions regarding remote sensing are necessary: remote measurement sensors can be "passive" and "active" but both record the intensity of a signal from a target. Passive sensors usually use the reflected spectrum of the sun. Active sensors are equipped with a light source, usually a laser, for illumination of the target. Sensors have "bands" or "channels", of specific wavelength within the electromagnetic spectrum. Target objects have a spectral signature based upon how they reflect and emit electromagnetic radiation. "Spectral resolution" refers to the number and width of discrete bands per sensor. The temporal resolution, or "revisit time", is very important in marine applications. This refers to the time period between repeat passes over an object. Data are delivered to the user in a matrix or "scene" of square picture elements (pixels). The pixel size corresponds to the "spatial resolution" of the sensor, which determines the smallest object detectable.

Satellite observations have been made on dedicated missions: "Ocean colour" has been measured since 1970s (CZCS) and reliable data has become available since 1999 (SeaWIFS), with high temporal coverage since 2002 (MODIS and MERIS). When looking at measurements relevant for primary production estimates, global chlorophyll 


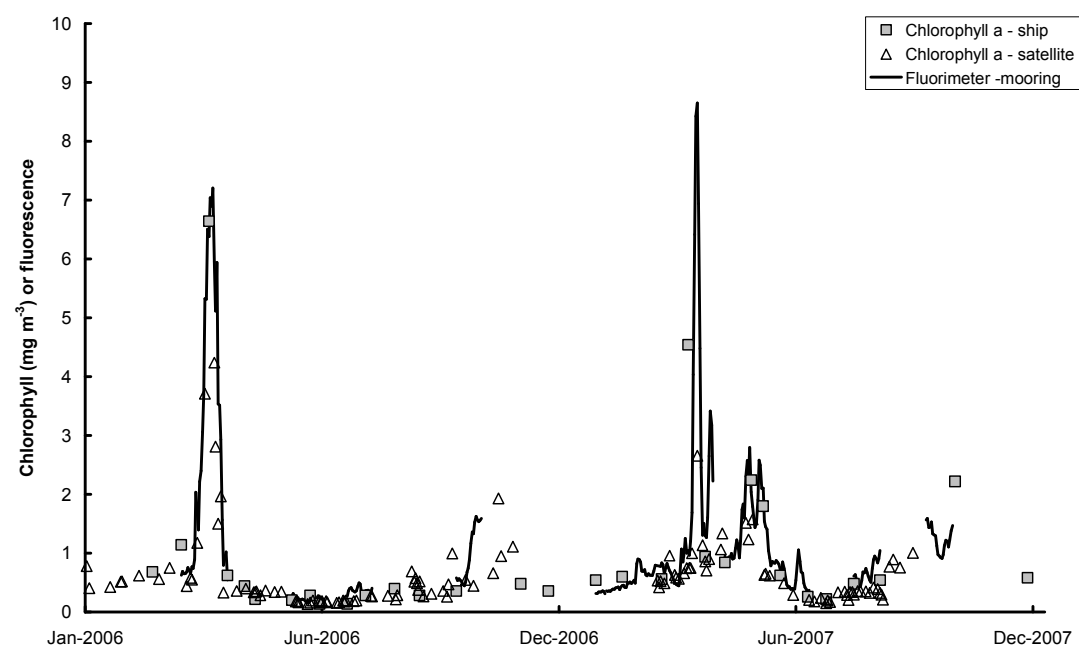

Fig. 3. Data comparison of phytoplankton chlorophyll measurements at a calibration site in the North Sea, the Oyster Grounds $\left(54^{\circ} 24^{\prime} 84 \mathrm{~N}\right.$, $\left.004^{\circ} 2^{\prime} 50 \mathrm{E}\right)$. Satellite observations are from daily MODIS scenes processed at Ifremer with the OC5 algorithm (Gohin et al., 2002), courtesy of Ifremer/Marcoast, ship based measurements are from field sampling by RIKZ, The Netherlands (www.waterbase.nl) and represent chlorophyll a as measured by extraction with organic solvent and analysis by HPLC, and moored fluorimeter data are collected using a jointly operated Cefas/RIKZ SmartBuoy and can be viewed or downloaded at (http://www.cefas.co.uk/data/marine-monitoring.aspx).

algorithms work well in most waters but not in shallow, turbid regions (Gregg and Casey, 2004). Therefore regional algorithms are in development for such "case II" waters, for example the European Space Agencies "MarCoast" project (2006-2008) aims to produce certified, validated water quality products for European waters ("no more maps without stats"). An important aspect when using remote sensing data is comparison with in-situ observations (ground-truthing) to ensure data robustness. Figure 3 gives an example of satellite, ship and buoy derived chlorophyll measurements at a site in the North Sea. The time series show very different phytoplankton bloom dynamics between the two consecutive years. In 2006 a single, large peak of chlorophyll in early April is followed by a long period of low surface chlorophyll during the summer, whereas in 2007 a series of large blooms occurred throughout the spring and early summer. Both years have evidence of increased chlorophyll in the autumn.

Other examples of remote sensing data output are water quality measures based on sediment load and light attenuation, ocean temperature and waves, the evaluation of bloom deposition (Schratzberger et al., 2008), and the study of environmental factors controlling shellfish growth (Smith and al., 2007). Remote sensing sets the spatial scale context often difficult to achieve by other means. This is particularly clear in the context of climate change. More observational data is required and the integration of remote measurements with other observations and ecosystem models will be very important.

\subsection{In-situ observations}

In this review "in-situ observations" include all measurements that are not made remotely. These can be genuinely in-situ measurements for example made by deploying sensors on moorings or drifters or by inserting them from landers into sediments, but also includes measurements made subsequently by inserting sensors into samples retrieved from the ecosystem, such as water, sediment cores, or even biota.

\subsubsection{Biogeochemical cycles}

Many of the measurements directed at quantifying processes such as the carbon cycle, and nutrient fluxes are described in other papers such as the ones on oceanic carbon measurements and observation of ocean nutrient environments, but briefly mentioned here because of their high relevance to ecosystem status. They are particularly important in the context of legislative control of water quality, and key criteria under many EU directives (Urban Waste Water Treatment Directive, Water Framework Directive, Nitrates Directive etc.) and OSPAR comprehensive procedure assessments (Tett et al., 2007).

Nitrate measurements are, for example, continuously made in-situ on Cefas SmartBuoys (http://www.cefas.co.uk/ data/marine-monitoring.aspx) using NAS3x nutrient analysers (http://envirotechinstruments.com/index.html) alongside a range of other instruments. Figure 4 depicts a SmartBuoy with its sensor payload. Using these sensors in combination with other measurements such as chlorophyll fluorescence and oxygen made at the same time from the same platform it is possible to identify the spring bloom timing, onset 


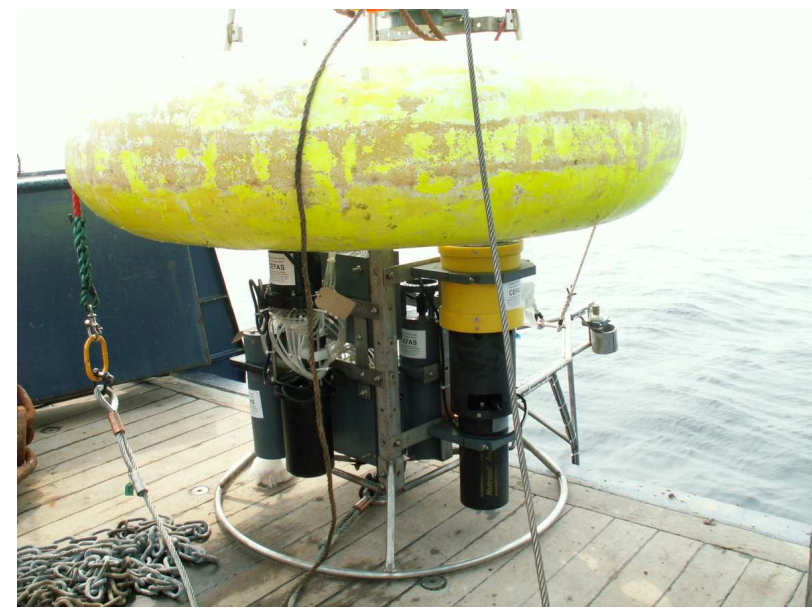

Fig. 4. Smartbuoy with sensor payload including 50-bag water sampler, nitrate analyser and ESM2 logger with chlorophyll fluoromer, PAR ( $1 \mathrm{~m}$ and $2 \mathrm{~m}$ ), conductivity, temperature and optical backscatter. Data telemetry by ORBCOMM satellite.

of stratification and nutrient limitation through the growing season. The high temporal resolution gives clearer insight into rates of change and tidal variability otherwise not captured by shipboard sampling.

A biosensor based on microbial utilisation of nitrate and nitrite has been commercialised by Unisense (http://www. unisense.com, the company website lists a large range of papers demonstrating the utility of the sensor), and has been tested for laboratory and field analysis of seawater samples. The sensor showed good correlation to traditional wet-chemistry analysis of nutrients used on an autoanalyser (Kirkwood et al., 1996)and has the advantage of using lesscostly equipment and not generating any hazardous chemical waste. Performance of the biochambers can be variable and the lifetime is limited, but for particular applications this sensor has very useful characteristics.

Spectral analysis in the UV range can be used to detect nitrate although careful calibration is required and problems can occur particularly in highly coloured or turbid coastal waters. Instruments are available from TRIOS (ProPS http: $/ /$ www.trios.de/index.php?option=com_content $\backslash \&$ view= article $\backslash \&$ id=199 $\backslash \&$ catid=45 $\backslash \&$ Itemid=74 $\backslash \&$ lang=en), and Satlantic (SUNA www.satlantic.com/suna/).

Sediment nutrients are rarely detected in-situ. While sampling techniques are evolving, such as lander-based deployments of gel sampling technologies (DET and DGT, (Zhang and Davison, 1999; Fones et al., 2001), these still require sample elution and analysis in the lab and sensors fully adapted to the measurement of nutrients in sediments are desirable.

A parameter of increasing importance to ecosystem studies is oxygen, both in the context of estimation of primary production, as well as being part of the evaluation of un-

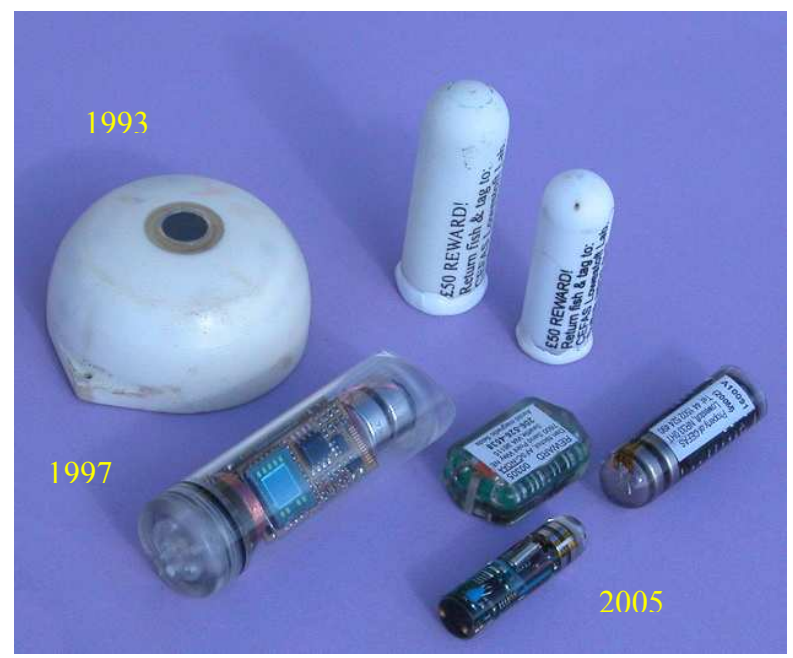

Fig. 5. A selection of electronic "archival" or "data storage" tags used to study the movements and behaviour of fish showing the reductions in size over timefrom Metcalfe et al. (2009b).

desirable disturbance and detection of low oxygen events. Oxygen measurements within the sediment and water column are key to providing insight on carbon fate and cycling in terms of benthic pelagic coupling and remineralisation pathways and rates. The latest generation of sensors such as the seabird oxygen sensor based on a redesign of the Clark polarographic membrane type (http://www.seabird. com/products/spec_sheets/43data.htm), and optodes which quantify dissolved oxygen concentrations based on fluorescent quenching of dyes immobilised in sensing foils, have allowed rapid progress (Tengberg et al., 2006). For measurements from SmartBuoys and other automated platforms, Anderaa optodes (http://www.aadi.no/aanderaa/welcome.aspx), have produced extremely useful data series. These optodes have been used for extended periods and while fouling is still an issue, robustness and reliability have been excellent. The high-frequency data collected over extended time periods has given insights into events and processes at a range of temporal scales (hours to weeks) that were not possible on the basis of discrete sporadic measurements achieved by traditional methods and platforms. Recently optodes deployed at three sites within the North Sea (Southern Bight, North Dogger and Oyster Grounds) on landers and buoys have provided insight into contrasting carbon coupling mechanisms and rates for two years in succession. Accompanied by current (Acoustic Doppler Current Profiler, ADCP), temperature, salinity, fluorescence and suspended load traces, they have highlighted processes that can drive oxygen depletion linked to the thermocline, the rate of such depletion events and the significance of storm induced resuspension in driving oxygen often down towards $40 \%$ saturation.

Oxygen in sediments is controlled by the supply of oxygen from the water column and consumption within the sediment, 
which is related to sediment type, carbon input and benthic fauna (micro to macro). The dynamic control on oxygen fluxes between sediment and water column is key to understanding ecosystem status. For recording oxygen profiles in sediments, Clark type glass microelectrodes such as those produced by Unisense (http://www.unisense.com/) have been used to good effect and by many groups. Unisense are maintaining a comprehensive literature list of published microsensor work over the last two decades (http://www.unisense. com/Default.aspx?ID=629). These electrodes are available in a range of different tip diameters and lengths and are surprisingly robust when inserted into sediment cores or into the sediment interface using bottom landers, as explored under the European project COBO (http://www.cobo.org.uk/). The requirements for new technologies for the study of continental margin benthic ecosystems and the need for benthic observatories are discussed at http://www.aslo.org/santafe2007.

Microelectodes provide point profiles at high resolution $(100 \mu \mathrm{m})$ to $\mathrm{mm}$ but can take a while to profile at high resolution and provide information at one point only. Recent introduction of planar oxygen optodes (Glud et al., 1996) now allows two-dimensional quantification of the variations in oxygen distribution at a spatial resolution of $0.1 \mathrm{~mm}$ over areas of several $\mathrm{cm}^{2}$. The optode penetrates the sediment like an inverted periscope, using a design similar to the SPI (Sediment Profile Imagery) camera developed by Rhoads and Germano (Rhoads et al., 1981) and enables examination of 2-D oxygen dynamics in relation to topography, sediment structure and bioturbation. Multiple oxygen profiles can be derived from each planar image. Based on this technology detection of $\mathrm{pH}$ has similarly been feasible using a planar optode approach (Stahl et al., 2005). SPI technology itself uses sediment colour images to examine sediment redox status, and links to faunal succession based on a model developed by Pearson and Rosenberg (Pearson and Rosenberg, 1978). Developments of this technology have linked time-lapse capability with fluorescent tracers or gel sampling to provide insight into sediment functioning and chemistry (Solan et al., 2004). In-situ detection of further chemical species such as carbon fractions, nutrients, metals and contaminants remains desirable.

Two parameters increasingly on the monitoring agenda are carbon dioxide and $\mathrm{pH}$, both of which are highly relevant in the context of ocean acidification. As the measurements surrounding these parameters in the ocean are subject to much consideration, the reader is referred to the detailed discussions within the recently published OceanSensors08 paper "Sensors and instruments for oceanic dissolved carbon measurements" (Schuster et al., 2009)

Further to the quantification of the chemicals involved in biogeochemical cycles, the identification and quantification of organisms or functional groups of micro-organisms driving these processes is of interest and this links to the species identification and enumeration discussed in Sect. 2.2.3.

\subsubsection{Primary productivity}

As outlined above, primary productivity - that is the assimilation of inorganic carbon into organic carbon by photosynthesising plants, forms the basis of the marine food chain. In the main, marine primary production is carried out by phytoplankton, i.e. small drifting mostly single cellular organisms. Quantifying primary production of phytoplankton is achieved in various ways; either measuring the rate of radio-labelled carbon incorporation (a discrete sample based method) or using sensors to estimate biomass based on chlorophyll-aconcentration in the water - as also outlined under remote sensing of ocean colour - or by measuring oxygen as product of photosynthesis.

In-situ measurements of chlorophyll are possible using fluorometers (for example Seapoint fluorometers as used on SmartBuoys, see http://www.seapoint.com/scf.htm) and used in deduction of primary production (Dennis, 2006; Dennis et al., 2006). A useful addition to the basic cholorphyll $a$ quantification are fluorometers that give more information about the health of the algal population and their photosynthetic yield. Examples are Fast repetition rate fluorometers (FRRF), Phytoflash and Pulse-Amplitude-Modulation (PAM) fluorometers, which provide a selective measure of the relative chlorophyll fluorescence quantum yield. (see http://www.chelsea.co.uk/Instruments\%20FASTtracka. htm, http://www.walz.com/index.html, and http://www. turnerdesigns.com/t2/instruments/phytoflash.html). With the help of the so-called "Saturation Pulse Method", the quantum yield of photosynthetic energy conversion can be derived. These methods still need calibration and checking with accepted carbon incorporation methods, but good matches between traditional and fluorescence-based production estimates have been reported (Kromkamp et al., 2008).

One controlling factor of primary production is the prevailing light field that may vary hourly, daily and seasonally. There are several optically active constituents (OAC) that affect the penetration of sunlight into the water column, namely suspended particulate matter (SPM), phytoplankton, and coloured dissolved organic material (CDOM) (Foden et al., 2008; Devlin et al., 2008). The light level may be measured directly over a range of wavelengths, thus giving valuable information on the spectral distribution underwater, or measured across the total photosynthetically active radiation (PAR) range of 400-700 nm (http://www.wetlabs.com/products/index.htm, http://www.turnerdesigns.com, http://www.licor.com). The attenuation of light $\left(K_{d}\right)$ can be measured directly be comparing irradiance values at two or more depths, or derived from knowledge of the OACs (Devlin et al., 2008) using a radiative transfer model such as HydroLight (http://www.sequoiasci.com/products/Hydrolight.aspx).

SPM may be measured by a transmissometer (http://www.seabird.com) or, more usually, optical back scatter (OBS) of infra-red beams. Many OBS or turbidity 
sensors are commercially available and several were recently assessed by the Alliance for Coastal Technologies (ACT - http://www.act-us.info/evaluation_reports.php). Further details regarding the size, and to some extent, the shape of the suspended particles may also be obtained by deploying a particle size analyser: (http://www.sequoiasci.com/products/LISST_Inst.aspx).

Another OAC, coloured dissolved organic matter (cDOM), may be determined by in-situ absorption or fluorescence at selected wavelengths. A recent Cefas project deployed a TriOS CDOM fluorometer (http: $/ /$ www.trios.de/index.php?option=com_content $\backslash \&$ view= article $\backslash \&$ id=83 $\backslash$ \&catid=46 $\backslash \&$ Itemid=75 $\backslash$ \&lang=en) as part of a sensor package to determine the light climate in UK water bodies (Foden et al., 2008).

A useful tool in which observations are brought together is the Ferrybox, a platform mounted on ships of opportunity, to collect high frequency data on regular transects (see http://www.noc.soton.ac.uk/ops/ferrybox_index.php and http://www.ferrybox.com/ and http://www.4h-jena.de/index. php?id=43 $\backslash \& \mathrm{~L}=0 \backslash \& \mathrm{~L}=1)$. A recent paper used continuous oxygen concentration records collected by ferrybox on cruise transects between Portsmouth (UK) and Bilbao (Spain) for a regional analysis of new production (Bargeron et al., 2006), which illustrates that the oxygen measurements discussed in Sect. 2.2.1 are also relevant to primary production estimates.

\subsubsection{Species detection}

The detection or identification of species within the marine environment is a field where sensors are of increasing relevance. While taxonomy has classically relied on morphology and optical identification, molecular biology has added a new dimension to the setting of species boundaries. These methods are of particular importance at the bottom of the size spectrum: in characterising microbial and planktonic communities. Automated optical methods, such as holocam (http://www.holocam.com) and other image analysis based sensing techniques are one group of tools. Automated analysis of size- and functional groups of primary producers can be undertaken by flow cytometry (http://www.cyto.purdue. edu/flowcyt/educate/pptslide.htm). However, although data is generated rapidly and instruments exist both in laboratory and in-situ format (http://www.cytobuoy.com), the interpretation of the data still requires expert opinion. Further work on establishing libraries and well-defined criteria for group identification is required.

DNA or RNA based methods such as hybridisation probe based sensors is another rapidly evolving field. Molecular biological methods for species detection will be discussed in detail by Jon Zehr and colleagues in this series of OceanSensor papers (Zehr, 2009) and significant progress on the use of molecular probes for the identification of microbial and phytoplankton species has been made by a group led by Chris Scholin at Monterey Bay Aquarium Research Institute
(MBARI), again as discussed in a separate paper given at OceanSenors08 (Scholin, 2009). Their Environmental Sample Processor (ESP) is possibly the furthest advanced technology for in-situ species detection. http://www.mbari.org/ muse/platforms/ESP.htm.

Molecular biological methods do not only aid the detection of individual species but can also yield useful information with regard to species diversity and population dynamics (Rynearson et al., 2006; Rynearson and Armbrust, 2004). Genetic information determined through the use of DNA/RNA fingerprinting and molecular biologically based sensors provide insights into many ecosystem processes and interactions.

When going from water column to sediment analysis, matrix effects make individual species detection even more technically difficult and so most analysis of meio- and macrofauna has relied on conventional grab techniques providing information about habitats and assemblages. Microbial probing is developing and fingerprints of functional groups, such as denitrifiers, nitrifiers, and sulphate reducers (Pratscher et al., 2009; Mills et al., 2008), have been described, but so far no methodology for in-situ sensing based on these probes has become available.

An optical method that allows direct insights into sediment structure and species within the sediment is the Sediment profile imagery (SPI) camera discussed under Sect. 2.2.1. Its application in understanding of pattern, scale and process in marine benthic systems has been described (Solan et al., 2003).

\subsubsection{Animal movements}

The advent of micro-electronics in the 1950s and the further development of integrated circuit (silicon chip) technology allowed, by the early 1990s, the development of electronic "data storage" or "archival" tags that could be made small enough to attach to, or implant into, individual fish (see review by Arnold and Dewar, 2001). These devices intermittently record and store information from on-board sensors that measure environmental variables such as pressure (to give depth), temperature and ambient daylight. Although early tags of this type were quite large, $(20-40 \mathrm{~g})$, they could store comparatively limited amounts of data $(30 \mathrm{k}-50 \mathrm{k}$ data points) and were expensive ( $\sim 700-800)$. Technology has since advanced rapidly and tags that can store in excess of a million data points, weigh 1-2 g (in water), and cost $£ 200$ 300 are now available (Metcalfe et al., 2009). Figure 4 illustrates the reduction of size of data storage tags designed for deployment on fish since the early 1990s.

The data from such tags not only provide fine-scale information about behaviour (e.g. vertical movements derived from pressure readings) but can also be used to determine geolocation (e.g. from records that provide an estimate of day length (to estimate latitude) and the time of local midday or midnight (to estimate longitude) if ambient daylight 
is recorded (Wilson et al., 1992; Hill, 1994; Metcalfe, 2001), or tidal data derived from pressure recordings when the fish remain at the seabed through a full $12 \mathrm{~h}$ tidal cycle (Metcalfe and Arnold, 1997; Hunter et al., 2003) on many occasions while the fish is at liberty. This behavioural and movement information can then be integrated with environmental data that were either recorded by the tag at the same time (e.g. water temperature), or that were collected independently (e.g. satellite data of sea surface temperature or biological productivity) for the same geographical area e.g. Sims et al. (2003).

More recently, sensors have been used directly to monitor detailed aspects of behaviour such as feeding. For example, temperature sensing data storage tags that monitor the difference between visceral and environmental temperatures have been used to monitor feeding events and estimate food intake in southern bluefin tuna (Gunn and Block, 2001) and tags equipped with movement sensors have been used to detect jaw movement (including feeding) events in penguins (Wilson et al., 2002) and cod (Metcalfe et al., 2008).

First results from these sort of electronic tagging studies provided exciting insights into the behaviour of individuals, revealing unprecedented levels of detail from fish behaving in their natural environment over extended periods of time. Understandably, early reports described movements over periods of weeks and months (Metcalfe and Arnold, 1997), but results spanning multi-year timescales are now appearing in the literature (Hunter et al., 2003, 2005). However, because tag returns, even for heavily exploited species, may be no more than $20-30 \%$, many hundreds of tags need to be deployed before it starts to become possible to draw conclusions at the scale of fish populations. Consequently, it is only now that this technology is beginning to deliver meaningful information that can be applied at the level of fish stocks (Hunter et al., 2005, 2006; Metcalfe, 2006).

Data collected from individual marine mammals or fish species can also provide insights into physical conditions in the oceans at sites where access by conventional sampling platforms is difficult, for example under Artic or Antarctic sea ice. For larger animals data can be transmitted back to shore stations via satellite or mobile phone networks.

While the primary purpose of telemetry studies with marine animals is to understand their movements, behaviour and distribution in relation to the environment, the environmental data itself has a value to oceanographers and criminologists, particularly when the animals are making large-scale movements in more inaccessible and poorly surveyed areas such as the southern Oceans. An example is the SEaOS (Southern elephant seals as oceanic samplers) project in which purposebuilt CTD sensors linked to satellite relayed data loggers deployed on Southern elephant seals are used to provide data on cross sectional samples of the main circum-Antarctic fronts and convergences as well as oceanographic data associated with the marginal ice zone and areas deep within it (Charrassin et al., 2008).

\subsubsection{Habitats}

Habitat characterisation is an integral of many of the parameters described above. Furthermore, habitats can be sensed remotely or mapped using optical and acoustic techniques (Birchenough et al., 2006). Acoustic sensors, such as side scan sonar, and optical hyperspectral instruments such as CASI do provide important information about the physical structure of seabed environments but they still require ground-truthing via conventional techniques (Eastwood et al., 2006).

\subsubsection{Pollutants}

A large number of biosensors have been developed to measure individual pollutants (Kröger et al., 2002; Kröger and Law, 2005) and many of these sensors could be used in ecosystem status related measurements. Many suffer problems with regard to stability, robustness, lifetime or simply commercial availability. For these reasons, few pollutant measurements are currently made in-situ, most rely on sample analysis by traditional chemical methods in dedicated laboratories. Efforts are being made to develop more sensors for pollutant analysis in the field.

In Table 2, a range of different biosensors is categorised according to their area of application in marine measurements. This list can be further substituted with physical and chemical sensors and would need updating to include further sensors described since 2004, but it gives a flavour of the breadth of academic research into this area, of which little has so far translated into routine monitoring tools.

Generally speaking most pollutant concentrations in the marine environment are relatively low due to dilution of terrestrial or atmospheric inputs. Therefore the problem for many sensors can be obtaining sufficiently low detection limits, and analyte enrichment techniques, such as solid phase extraction or the use of passive samplers combined with conventional chemical analysis in laboratory settings is frequently applied instead of direct sensing. Integration of passive sampling or analyte enrichment techniques with in-situ sensors is a promising area for further development.

\section{Conclusions and forward look}

The sensors and systems described above cover a wide range of applications, utilising varied deployment platforms and sample matrices. Gaps, such as automated systems quantifying secondary production or sensors that further investigate processes within sediments, have been highlighted alongside the outline of existing systems and current developments.

In summary the big questions when assessing the marine ecosystem are: do we see the diversity of plants and animals we would expect, are there enough individuals of the species we would expect to see and not too many alien species, are these plants and animals generally healthy (not 
Table 2. Examples of biosensors relevant to marine applications (note: the table is by no means exhaustive, but only intended to give a first idea of the breadth of available systems).

\begin{tabular}{|c|c|c|}
\hline Application area & Analyte & Reference \\
\hline \multirow[t]{2}{*}{ Eutrophication } & Nitrate and nitrite & $\begin{array}{l}\text { (Aylott et al., 1997) (Kirstein et al., 1999) } \\
\text { (Mbeunkui et al., 2002) (Moretto et al., 1998) } \\
\text { (Larsen et al., 1997) (Nielsen et al., 2004) (Pa- } \\
\text { tolsky et al., 1998) (Prest et al., 1997) (Ramsay } \\
\text { and Wolpert, 1999; Revsbech, 2005) (Sasaki } \\
\text { et al., 1998) (Takayama, 1998; Zazoua et al., } \\
\text { 2009) }\end{array}$ \\
\hline & Phosphate & $\begin{array}{l}\text { (Engblom, 1998) (Kwan et al., 2005) (Naka- } \\
\text { mura et al., 1999) (Nakamura et al., 1999) (Par- } \\
\text { ellada et al., 1998) }\end{array}$ \\
\hline \multirow[t]{5}{*}{ Food safety } & Algal toxins (for & (Campàs et al., 2008) (Carter et al., 1993) \\
\hline & example anatoxin-a, & (Cheun et al., 1998) (Devic et al., 2002) \\
\hline & brevetoxin, domoic & (Kreuzer et al., 2002) (Marquette et al., 1999; \\
\hline & $\begin{array}{l}\text { acid, okadaic acid, sax- } \\
\text { itoxin and tetrodotoxin) }\end{array}$ & $\begin{array}{l}\text { Shitanda et al., 2009) (Tang et al., 2002) (Volpe } \\
\text { et al., 2009) }\end{array}$ \\
\hline & Pathogens & (Leonard et al., 2003) \\
\hline $\begin{array}{l}\text { Organisms } \\
\text { detection/taxonomy }\end{array}$ & $\begin{array}{l}\text { Nucleic acids } \\
\text { (DNA/RNA) }\end{array}$ & $\begin{array}{l}\text { (Campas and Katakis, 2004;Diercks et al., } \\
\text { 2008a) (Diercks et al., 2008b) (Drummond et } \\
\text { al., 2003) (Epstein et al., 2002) (Gooding, 2002) } \\
\text { (Homs, 2002) (Kerman et al., 2004) (Kulag- } \\
\text { ina et al., 2006) (Vercoutere and Akeson, 2002) } \\
\text { (Palecek and Jelen, 2002) (Wang, 2002) }\end{array}$ \\
\hline \multirow[t]{4}{*}{ Pollutants } & Pesticides & $\begin{array}{l}\text { (Chouteau et al., 2005) (Mallat et al., 2001) } \\
\text { (Mallat et al., 2001) (Penalva et al., 1999; Solé } \\
\text { et al., 2003b) (Solé et al., 2003a) (Suri et al., } \\
\text { 2002) (Vedrine et al., 2003) }\end{array}$ \\
\hline & $\begin{array}{l}\text { Polycyclic aromatic hy- } \\
\text { drocarbons (PAH) }\end{array}$ & $\begin{array}{l}\text { (Fähnrich et al., 2003) (Gobi et al., 2003) } \\
\text { (Chang et al., 2004) }\end{array}$ \\
\hline & Steroids & $\begin{array}{l}\text { (Draisci et al., 2000) (Kröger et al., 2002) (Mo } \\
\text { et al., 1999) }\end{array}$ \\
\hline & Tributyltin & (Horry et al., 2007) (Thouand et al., 2003) \\
\hline \multirow[t]{4}{*}{ Trace metals } & Cadmium & (Chouteau et al., 2004) \\
\hline & $\begin{array}{l}\text { Cadmium, Copper, } \\
\text { Mercury and Tin }\end{array}$ & (Rodriguez et al., 2004) \\
\hline & Lead & (Lu et al., 2003) \\
\hline & Zinc and Chromate & (Ivask et al., 2002) \\
\hline
\end{tabular}

exhibiting unnaturally high levels of disease) and is the system stable and productive? If we can answers these questions we can try to manage towards the ambition described in the UK Marine Monitoring and Assessment Strategy (UKMMAS), for "clean, healthy, safe, productive and biologically diverse oceans and seas" (http://www.defra.gov.uk/ environment/marine/about.htm).

Sensors can be used to make important observations, which form the basis for ecosystem status assessment. The range of observations covered under this heading is ex- tremely diverse - ranging from in-situ quantification of individual chemicals, to effects measurements of pollutants, individual or cumulative, to tracking of animal movements and even remote observations of large sea areas. The matrixes involved can be water, sediment, biota or even the atmosphere above the sea. In addition to the availability of sensors for different parameters, their usefulness is determined by performance characteristics such as stability, sensitivity, size, power consumption, fouling resistance, cost, longevity and ability to interface with different observational platforms, as 
ecosystem status observations rely on data being provided at the appropriate temporal and spatial resolution. Some sensors have been discussed above; many more are available or emerging. For new sensors, it is down to a dialogue between sensor developer and problem holder to discuss appropriate specifications and estimate how realistic it is to develop an appropriate tool. Bridging the gap between what is theoretically a good idea and academically possible and what makes a good routine monitoring tool is often not a small challenge. It is clear though, that many useful sensors and techniques are available and many more desirable, if progress towards a "clean, safe, healthy, biodiverse and productive sea" is going to be made using the "ecosystem approach to management".

\section{Appendix A}

\section{Related web links}

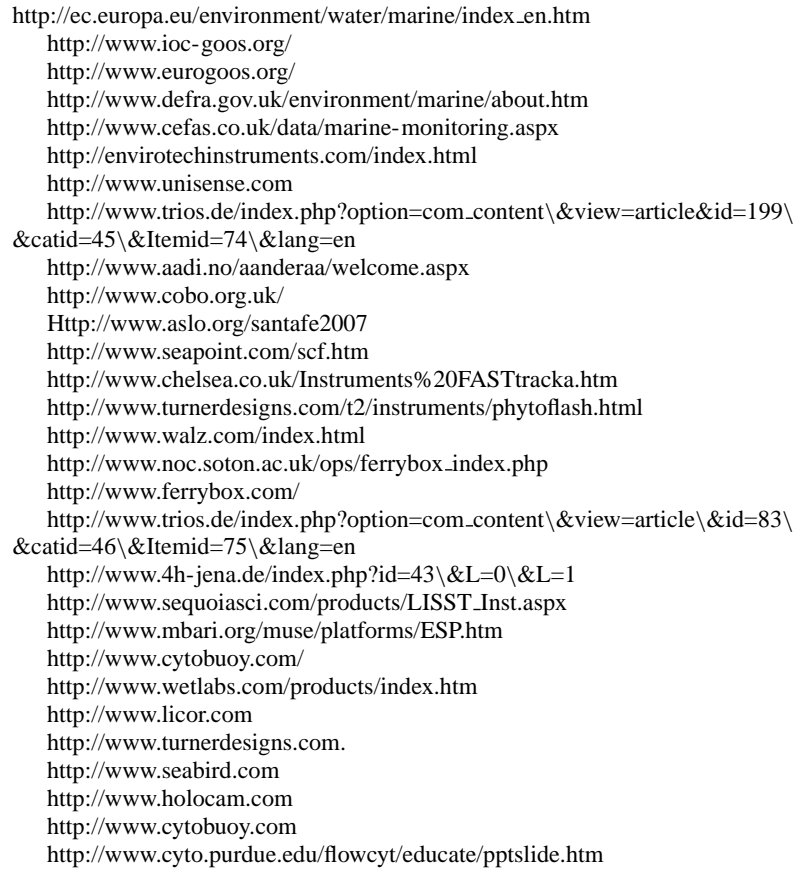

Acknowledgements. The authors would like to acknowledge funding from Defra (under contract SLA25) and the valuable discussions that took part at the Ocean Sensors 08 workshop in Warnemünde.

Edited by: R. Prien

\section{References}

Arnold, G. P. and Dewar, H.: Electronic tags in marine fisheries research: A 30 year perspective., in: Electronic tagging and tracking in marine fisheries, edited by: Nielsen, J. R. S. J. L., Kluwer Academic Press, Dordrecht, The Netherland, 7-64, 2001.

Aylott, J. W., Richardson, D. J., and Russell, D. A.: Optical biosensing of nitrate ions uisng a sol-gel immobilized nitrate reductase, Analyst, 122, 77-80, 1997.
Bargeron, C. P., Hydes, D. J., Woolf, D. K., Kelly-Gerreyn, B. A., and Qurban, M. A.: A regional analysis of new production on the northwest european shelf using oxygen fluxes and ship-ofopportunity, Estuar. Coas. Shelf S., 69, 478-490, 2006.

Birchenough, S. N. R., Boyd, S. E., Coggan, R. A., Limpenny, D S., Meadows, W. J., and Rees, H. L.: Lights, camera and acoustics: Assessing macrobenthic communities at a dredged material disposal site off the north east coast of the uk, J. Marine Syst., 62, 204-216, 2006.

Campas, M. and Katakis, I.: DNA biochip arraying, detection and amplification strategies, TRAC Trends In Analytical Chemistry, 23, 49-62, 2004.

Campàs, M., de la Iglesia, P., Le Berre, M., Kane, M., Diogène, J., and Marty, J.-L.: Enzymatic recycling-based amperometric immunosensor for the ultrasensitive detection of okadaic acid in shellfish, Biosens. Bioelectron., 24, 716-722, 2008.

Carter, R. M., Poli, M. A., Pesavento, M., Sibley, D. E. T., Lubrano, G. J., and Guilbault, G. G.: Immunoelectrochemical biosensors for detection of saxitoxin and brevetoxin, ImmunoMethods, 3 , 128-133, 1993.

Chang, S. T., Lee, H. J., and Gu, M. B.: Enhancement in the sensitivity of an immobilized cell-based soil biosensor for monitoring pah toxicity, Sensors and Actuators B Chemical, 97, 272-276, 2004.

Charrassin, J.-B., Hindell, M., Rintoul, S., Roquet, F., Sokolov, S., Biuw, M., Costa, D., Boehme, L., Lovell, P., Coleman, R., Timmermann, R., Meijers, A., Meredith, M., Park, Y.-H., Bailleul, F., Goebel, M., Tremblay, Y., Bost, C.-A., McMahon, C., Field, I., Fedak, M., and Guinet, C.: Southern ocean frontal structure and sea-ice formation rates revealed by elephant seals, P. Natl Acad. Sci., 105, 11634-11639, 2008.

Cheun, B. S., Loughran, M., Hayashi, T., Nagashima, Y., and Watanabe, E.: Use of a channel biosensor for the assay of paralytic shellfish toxins, Toxicon, 36, 1371-1381, 1998.

Chouteau, C., Dzyadevych, S., Chovelon, J. M., and Durrieu, C.: Development of novel conductometric biosensors based on immobilised whole cell chlorella vulgaris microalgae, Biosens. Bioelectron., 19, 1089-1096, 2004.

Chouteau, C., Dzyadevych, S., Durrieu, C., and Chovelon, J.-M.: A bi-enzymatic whole cell conductometric biosensor for heavy metal ions and pesticides detection in water samples, Biosens. Bioelectron., 21, 273-281, 2005.

Dennis, A., Forster, R. M., Mills, D. K., and Greenwood, N.: The use of high-frequency observations in the calculation of primary production, Challenger conference, 2006.

Dennis, A.: The calculation of primary production using highfrequency data from data-buoys in uk waters, NOC Southampton and Cefas, 2006

Devic, E., Li, D. H., Dauta, A., Henriksen, P., Codd, G. A., Marty, J. L., and Fournier, D.: Detection of anatoxin-a(s) in environmental samples of cyanobacteria by using a biosensor with engineered acetylcholinesterases, Appl. Environ. Microbiol., 68, 4102-4106, 2002.

Devlin, M. J., Barry, J., Mills, D. K., Gowen, R. J., Foden, J., Sivyer, D., and Tett, P.: Relationships between suspended particulate material, light attenuation and secchi depth in uk marine waters, Estuar. Coast. Shelf S., 79, 429-439, 2008.

Dickey, T. D.: Physical-optical-biological scales relevant to recruitment in large marine ecosystems., in: Large marine ecosystems: 
Patterns, processes, and yields, edited by: Sherman, K., Alexander, L. M., and Gold, B. D., Am. Assoc. Adv. Sci. Publ, 90, 82-98, 1990.

Diercks, S., Metfies, K., and Medlin, L. K.: Development and adaptation of a multiprobe biosensor for the use in a semi-automated device for the detection of toxic algae, Biosens. Bioelectron., 23, 1527-1533, 2008a.

Diercks, S., Metfies, K., Schröder, F., Medlin, L. K., and Colijn, F.: Detection of phytoplankton with nucleic acid sensors NATO Security through Science Series, C: Environmental Security, 285300, 2008 b.

Draisci, R., Volpe, G., Compagnone, D., Purificato, I., delli Quadri, F., and Palleschi, G.: Development of an electrochemical elisa for the screening of 17b-estradiol and application to bovine serum, Analyst, 125, 1419-1423, 2000.

Drummond, T. G., Hill, M. G., and Barton, J. K.: Electrochemical DNA sensors, Nature Biotechnology, 21, 1192-1199, 2003.

Eastwood, P. D., Souissi, S., Rogers, S. I., Coggan, R. A., and Brown, C. J.: Mapping seabed assemblages using comparative top-down and bottom-up classification approaches, Can. J. Fish. Aquat. Sci., 63, 1536-1548, 2006.

Engblom, S. O.: The phosphate sensor, Biosens. Bioelectron., 13, 981-994, 1998.

Epstein, J. R., Biran, I., and Walt, D. R.: Fluorescence-based nucleic acid detection and microarrays, Anal. Chim. Acta, 469, 3 36, 2002.

Fa"hnrich, K. A., Pravda, M., and Guilbault, G. G.: Disposable amperometric immunosensor for the detection of polycyclic aromatic hydrocarbons (pahs) using screen-printed electrodes, Biosens. Bioelectron., 18, 73-82, 2003.

Foden, J., Sivyer, D. B., Mills, D. K., and Devlin, M. J.: Spatial and temporal distribution of chromophoric dissolved organic matter (cdom) fluorescence and its contribution to light attenuation in uk waterbodies, Estuar. Coast. Shelf S., 79, 707-717, 2008.

Fones, G. R., Davison, W., Holby, O., Jorgensen, B. B., and Thamdrup, B.: High-resolution metal gradients measured by in situ $\mathrm{dgt} /$ det deployment in black sea sediments using an autonomous benthic lander, Limnol. Oceanogr., 46, 982-988, 2001.

Glud, R. N., Ramsing, N. B., Gundersen, J. K., and Klimant, I.: Planar optrodes: A new tool for fine scale measurements of twodimensional o sub(2) distribution in benthic communities, Mar. Ecol. Prog. Ser., 140, 1-3, 1996.

Gobi, K. V., Sasaki, M., Shoyama, Y., and Miura, N.: Highly sensitive detection of polycyclic aromatic hydrocarbons (pahs) and association constants of the interaction between pahs and antibodies using surface plasmon resonance immunosensor, Sensors And Actuators B Chemical, 89, 137-143, 2003.

Gohin, F., Druon, J. N., and Lampert, L.: A five channel chlorophyll concentration algorithm applied to sea wifs data processed by seadas in coastal waters, Int. J. Remote Sens., 23, 1639-1661, 2002

Gooding, J. J.: Electrochemical DNA hyhridization biosensors, Electroanalysis, 14, 1149-1156, 2002.

Gregg, W. W. and Casey, N. W.: Global and regional evaluation of the seawifs chlorophyll data set, Remote Sens. Environ., 93, 463-479, 2004.

Gunn, J. and Block, B.: Advances in acoustic, archival, and satellite tagging of tunas, in: Tuna: Physiology, ecology and evolution., edited by: Block, B. A. and Stevens, E. D, Academic Press, 167-
219, 2001.

Harashima, A., Kimoto, T., Wakabayashi, T., and Toshiyasu, T.: Verification of the silica deficiency hypothesis based on biogeochemical trends in the aquatic continuum of lake biwa-yodo river-seto inland sea, Japan, Ambio, 35, 36-42, 2006.

Hill, R.: Theory of geolocation by light levels, in: Elephant seals: Population ecology, behavior, and physiology, edited by: Le Boeuf, B. J. and Laws, R. M., University of California Press, Berkeley, 227-236, 1994.

Hiscock, K., Langmead, O., Warwick, R., et al.: Identification of seabed indicator species from time-series and other studies to support implementation of the eu habitats and water framework directives, Report to the Joint Nature Conservation Committee and the Environment Agency from the Marine Biological Association. Plymouth: Marine Biological Association, JNCC Contract F90-01-705, 109 pp., 2004.

Homs, W. C. I.: DNA sensors, Anal. Lett., 35, 1875-1894, 2002.

Horry, H., Charrier, T., Durand, M.-J., Vrignaud, B., Picart, P., Daniel, P., and Thouand, G.: Technological conception of an optical biosensor with a disposable card for use with bioluminescent bacteria Sensors and Actuators B, 122, 527-534, 2007.

Hunter, E., Aldridge, J. N., Metcalfe, J. D., and Arnold, G. P.: Geolocation of free-ranging fish on the european continental shelf as determined from environmental variables. I. Tidal location method, Mar. Biol., 142, 601-609, 2003.

Hunter, E., Buckley, A. A., Stewart, C., and Metcalfe, J. D.: Migratory behaviour of the thornback ray, raja clavata 1 in the southern north sea, J. Mar. Biol. Assoc., 85, 1095-1105, 2005.

Hunter, E., Berry, F., Buckley, A. A., Stewart, C., and Metcalfe, J. D.: Seasonal migration of thornback rays and implications for closure management, J. Appl. Ecol., 43, 710-720, 2006.

Ivask, A., Virta, M., and Kahru, A.: Construction and use of specific luminescent recombinant bacterial sensors for the assessment of bioavailable fraction of cadmium, zinc, mercury and chromium in the soil, Soil Biol. Biochem., 34, 1439-1447, 2002.

Kerman, K., Kobayashi, M., and Tamiya, E.: Recent trends in electrochemical DNA biosensor technology, Meas. Sci. Technol., 15, R1-R11, 2004.

Kirkwood, D. S., Aminot, A., and Carlberg, S. R.: The 1994 quastimeme laboratory performance study: Nutrients in seawater and standard solutions, Mar. Pollut. Bull., 32, 640-645, 1996.

Kirstein, D., Kirstein, L., Scheller, F., Borcherding, H., Ronnenberg, J., Diekmann, S., and Steinrucke, P.: Amperometric nitrate biosensors on the basis of pseudomonas stutzeri nitrate reductase, J. Electroanal. Chemi., 474, 43-51, 1999.

Kreuzer, M. P., Pravda, M., O'Sullivan, C. K., and Guilbault, G. G.: Novel electrochemical immunosensors for seafood toxin analysis, Toxicon, 40, 1267-1274, 2002.

Kröger, S., Piletsky, S., and Turner, A. P. F.: Biosensors for marine pollution research, monitoring and control, Mar. Pollut. Bull., 45, 24-34, 2002.

Kröger, S. and Law, R. J.: Sensing the sea, Trends Biotechnol., 23(5), 250-256, 2005.

Kromkamp, J. C., Dijkman, N. A., Peene, J., Simis, S. G. H., and Gons, H. J.: Estimating phytoplankton primary production in lake ijsselmeer (the netherlands) using variable fluorescence (pam-frrf) and c-uptake techniques, Eur. J. Phycol., 43, 327-344, 2008. 
Kulagina, N. V., Mikulski, C. M., Gray, S., Ma, W., Doucette, G. J., Ramsdell, J. S., and Pancrazio, J. J.: Detection of marine toxins, brevetoxin-3 and saxitoxin, in seawater using neuronal networks, Environ. Sci. Technol., 40, 578-583, 2006.

Kwan, R. C. H., Leung, H. F., Hon, P. Y. T., Barford, J. P., and Renneberg, R.: A screen-printed biosensor using pyruvate oxidase for rapid determination of phosphate in synthetic wastewater, Appl. Microbiol. and Biotechnol., 66, 377-383 2005.

Larsen, L. H., Kjaer, T., and Revsbech, N. P.: A microscale no3- biosensor for environmental applications, Anal. Chem., 69, 3527-3531, 1997.

Leonard, P., Hearty, S., Brennan, J., Dunne, L., Quinn, J., Chakraborty, T., and O'Kennedy, R.: Advances in biosensors for detection of pathogens in food and water, Enzyme Microb. Tech., 32, 3-13, 2003.

Lu, Y., Liu, J., Li, J., Bruesehoff, P. J., Pavot, C. M. B., and Brown, A. K.: New highly sensitive and selective catalytic DNA biosensors for metal ions, Biosens. Bioelectron., 18, 529-540, 2003.

Mallat, E., Barzen, C., Abuknesha, R., Gauglitz, G., and Barceló, D.: Fast determination of paraquat residues in water by an optical immunosensor and validation using capillary electrophoresisultraviolet detection, Anal. Chim. Acta, 427, 165-171, 2001.

Marquette, C. A., Coulet, P. R., and Blum, L. J.: Semi-automated membrane based chemiluminescent immunosensor for flow injection analysis of okadaic acid in mussels, Anal. Chim. Acta, 398, 173-182, 1999.

Mbeunkui, F., Richaud, C., Etienne, A. L., Schmid, R. D., and Bachmann, T. T.: Bioavailable nitrate detection in water by an immobilized luminescent cyanobacterial reporter strain, Appl. Microbiol. Biotechnol., 60, 306-312, 2002.

Metcalfe, J. D. and Arnold, G. P.: Tracking fish with electronic tags, Nature, 387, 665-666, 1997.

Metcalfe, J. D.: Summary report of a workshop on daylight measurements for geolocation in animal telemetry, in: Electronic tagging and tracking in marine fisheries reviews: Methods and technologies in fish biology and fisheries, edited by: Sibert, J. and Nielsen, J., Kluwer Academic Press, Dordrecht, The Netherlands, 331-342, 2001.

Metcalfe, J. D.: Fish population structuring in the north sea, J. Fish Biol., 69, 48-65, 2006.

Metcalfe, J. D., Righton, D. A., Hunter, E., and Eastwood, P.: Migration and habitat choice in marine fishes, in: Fish behaviour, edited by: Magnhagen, C., Braithwaite, V. A., Forsgren, E., and Kapoor, B. G., Science Publishers Inc., Enfield, USA,187-223, 2008.

Metcalfe, J. D., Fulcher, M. C., Clarke, S. R., Challiss, M. J., and Heatherington, S.: An archival tag for monitoring key behaviours (feeding and spawning) in fish, in: Tagging and Tracking of Marine Animals with Electronic Devices, edited by: Nielsen, J. L., Arrizabalaga, H., Fragoso, N., Hobday, A., Lutcavage, M., and Sibert, J., Methods and Technologies in Fish Biology and Fisheries, 9, 243-254, 2009.

Mills, H. J., Hunter, E., Humphrys, M., Kerkhof, L., McGuinness, L., Huettel, M., and Kostka, J. E.: Characterization of nitrifying, denitrifying, and overall bacterial communities in permeable marine sediments of the northeastern gulf of mexico, Appl. Environ. Microbiol., 74, 4440-4453, 2008.

Mo, Z. H., Long, X., and Fu, W.: A new sandwich-type assay of estrogen using piezoelectric biosensor immobilized with estrogen response element, Anal. Commun., 36, 281-283, 1999.

Moretto, L. M., Ugo, P., Zanata, M., Guerriero, P., and Martin, C. R.: Nitrate biosensor based on the ultrathin-film composite membrane concept, Anal. Chem., 70, 2163-2166, 1998.

Nakamura, H., Hasegawa, M., Nomura, Y., Arikawa, Y., Matsukawa, R., Ikebukuro, K., and Karube, I.: Development of a highly sensitive chemiluminescence flow-injection analysis sensor for phosphate-ion detection using maltose phosphorylase, J. Biotechnol., 75, 127-133, 1999.

Nielsen, M., Larsen, L. H., Jetten, M. S. M., and Revsbech, N. P. Bacterium-based no2 - biosensor for environmental applications, Appl. Environ. Microbiol., 70 6551-6558, 2004.

Palecek, E. and Jelen, F.: Electrochemistry of nucleic acids and development of DNA sensors, Critical Reviews In Analytical Chemistry, 32, 261-270, 2002.

Parellada, J., Narvaez, A., Lopez, M. A., Dominguez, E., Fernandez, J. J., Pavlov, V., and Katakis, I.: Amperometric immunosensors and enzyme electrodes for environmental applications, Anal. Chim. Acta, 362, 47-57, 1998.

Patolsky, F., Katz, E., Helegshabtai, V., and Willner, I.: A crosslinked microperoxidase-11 and nitrate reductase monolayer on a gold electrode - an integrated electrically contacted electrode for the bioelectrocatalyzed reduction of no3, Chemistry-A European Journal, 4, 1068-1073, 1998.

Pearson, T. H. and Rosenberg, R.: Macrobenthic succession in relation to organic enrichment and pollution of the marine environment, Mar. Biol. Annu. Rev., 16, 229-311, 1978.

Penalva, J., Gonzalez-Martinez, M., Puchades, R., Maquieira, A., Marco, M. P., and Barcelo, D.: Immunosensor for trace determination of irgarol in seawater using organic media, Anal. Chim. Acta, 387, 227-233, 1999.

Pratscher, J., Stichternoth, C., Fichtl, K., Schleifer, K.-H., and Braker, G.: Application of recognition of individual genesfluorescence in situ hybridization (ring-fish) to detect nitrite reductase genes (nirk) of denitrifiers in pure cultures and environmental samples, Appl. Environ. Microbiol., 75, 802-810, 2009.

Prest, A. G., Winson, M. K., Hammond, J. R. M., and Stewart, G.: The construction and application of a lux-based nitrate biosensor, Lett. Appl. Microbiol., 24, 355-360, 1997.

Ramsay, G. and Wolpert, S. M.: Utility of wiring nitrate reductase by alkylpyrroleviologen-based redox polymers for electrochemical biosensor and bioreactor applications, Anal. Chem., 71, 504506, 1999.

Rees, H. L., Boyd, S. E., Schratzberger, M., and Murray, L. A.: Benthic indicators of anthropogenic effects: Practical considerations in meeting regulatory needs., International Council for the Exploration of the Sea (CM Papers and Reports),CM 2003/J:04, 20, 2003

Revsbech, N. P.: Analysis of microbial communities with electrochemical microsensors and microscale biosensors, Methods in Enzymology, 397, 147-166, 2005.

Rhoads, D. C. and Germano, J. D.: Characterization of organismsediment relations using sediment profile imagining - an efficient Method of Remote Ecological Monitoring of the Seafloor (Remots TM System), Mar. Ecol. Prog. Ser., 8, 115-128, 1982.

Rodriguez, B. B., Bolbot, J. A., and Tothill, I. E.: Development of urease and glutamic dehydrogenase amperometric assay for heavy metals screening in polluted samples, Biosens. Bioelectron., 19, 1157-1167, 2004. 
Rogers, S. I. and Greenaway, B.: A uk perspective on the development of marine ecosystem indicators, Mar. Pollut. Bull., 50, 9-19, 2005.

Rynearson, T. A. and Armbrust, E. V.: Genetic differentiation among populations of the planktonic marine diatom ditylum brightwellii (bacillariophyceae), J. Phycol., 40, 34-43, 2004.

Rynearson, T. A., Newton, J. A., and Armbrust, E. V.: Spring bloom development, genetic variation, and population succession in the planktonic diatom ditylum brightwellii, Limnol. Oceanogr., 51, 1249-1261, 2006.

Sasaki, S., Karube, I., Hirota, N., Arikawa, Y., Nishiyama, M., Kukimoto, M., Horinouchi, S., and Beppu, T.: Application of nitrite reductase from alcaligenes faecalis s-6 for nitrite measurement, Biosens. Bioelectron., 13, 1-5, 1998.

Scholin, C. A.: What are "ecogenomic sensors?" - a review and thoughts for the future, Ocean Sci. Discuss., 6, 191-213, 2009, http://www.ocean-sci-discuss.net/6/191/2009/.

Schratzberger, M., Forster, R. M., Goodsir, F., and Jennings, S.: Nematode community dynamics over an annual production cycle in the central north sea, Mar. Environ. Res., 66, 508-519, 2008.

Schuster, U., Hannides, A., Mintrop, L., and Körtzinger, A.: Sensors and instruments for oceanic dissolved carbon measurements, Ocean Sci. Discuss., 6, 491-524, 2009,

http://www.ocean-sci-discuss.net/6/491/2009/.

Shitanda, I., Takamatsu, S., Watanabe, K., and Itagaki, M.: Amperometric screen-printed algal biosensor with flow injection analysis system for detection of environmental toxic compounds, Electrochimica Acta, 54, 4933-4936, 2009.

Sims, D. W., Southall, E. J., Richardson, A. J., Reid, P. C., and Metcalfe, J. D.: Seasonal movements and behaviour of basking sharks from archival tagging no evidence of winter hibernation, Mar. Ecol. Prog. Ser., 248, 187-196, 2003.

Smith, M. T. and Whelpdale, P.: Environmental variables and their influence on growth of the great scallop (pecten maximus) in the English Channel UK, ICES, CM G:08, 2007.

Solan, M., Germano, J. D., Rhoads, D. C., Smith, C., Michaud, E., Parry, D., Wenzhöfer, F., Kennedy, B., Henriques, C., Battle, E., Carey, D., Iocco, L., Valente, R., Watson, J., and Rosenberg, R.: Towards a greater understanding of pattern, scale and process in marine benthic systems: A picture is worth a thousand worms, $\mathrm{J}$. Exp. Mar. Biol. Ecol., 285-286, 313-338, 2003.

Solan, M., Wigham, B. D., Hudson, I. R., Kennedy, R., Coulon, C. H., Norling, K., Nilsson, H. C., and Rosenberg, R.: In situ quantification of bioturbation using time-lapse fluorescent sediment profile imaging (f-spi), luminophore tracers and model simulation, Mar. Ecol. Prog. Ser., 271, 1-12, 2004.

Solé, S., Merkoçi, A., and Alegret, S.: Determination of toxic substances based on enzyme inhibition. Part ii. Electrochemical biosensors for the determination of pesticides using flow systems, Critical Rev. Anal. Chem., 33, 127-143, 2003 a.

Solé, S., Merkoçi, A., and Alegret, S.: Determination of toxic substances based on enzyme inhibition. Part i. Electrochemical biosensors for the determination of pesticides using batch procedures, Critical Rev. Anal. Chem., 33, 89-126, 2003 b.

Suri, C. R., Raje, M., and Varshney, G. C.: Immunosensors for pesticide analysis antibody production and sensor development, Critical Rev. Biotechnol., 22, 15-32, 2002.
Takayama, K.: Biocatalyst electrode modified with whole-cells of p-denitrificans for the determination of nitrate, Bioelectroch. Bioener., 45, 67-72, 1998.

Tang, A. X. J., Pravda, M., Guilbault, G. G., Piletsky, S., and Turner, A. P. F.: Immunosensor for okadaic acid using quartz crystal microbalance, Anal. Chim. Acta, 471, 33-40, 2002.

Tengberg, A., Hovdenes, J., Andersson, J. H., Brocande, O., Diaz, R., Hebert, D., Arnerich, T., Huber, C., Koerzinger, A., Khripounoff, A., Rey, F., Roenning, C., Sommer, S., and Stangelmayer, A.: Evaluation of a life time based optode to measure oxygen in aquatic systems, Limnol. Oceanogr. Methods, 4, 717, 2006.

Tett, P., Gowen, R., Mills, D., Fernandes, T., Gilpin, T., Huxham, M., Kennington, K., Read, P., Service, M., Wilkinson, M., and Malcolm, S.: Defining and detecting undesirable disturbance in the context of marine eutrophication, Mar. Pollut. Bull., 55, 282 297, 2007.

Thouand, G., Horry, H., Durand, M. J., Picart, P., Bendriaa, L., Daniel, P., and DuBow, M. S.: Development of a biosensor for on-line detection of tributyltin with a recombinat escherischia coli strain, Appl. Microbial Biotechnol., 62, 218-225, 2003.

Urban Jr., E. R., Sundby, B., Malanotte-Rizzoli, P., and Melillo, J. M.: Watersheds, bays, and bounded seas, the science and management of semi-enclosed marine systems, Island Press, 288 pp., 2008.

Vedrine, C., Leclerc, J. C., Durrieu, C., and Tran-Minh, C.: Optical whole-cell biosensor using chlorella vulgaris designed for monitoring herbicides, Biosens. Bioelectron., 18, 457-463, 2003.

Vercoutere, W. and Akeson, M.: Biosensors for DNA sequence detection, Current Opinion In Chemical Biology, 6, 816-822, 2002.

Volpe, G., Cotroneo, E., Moscone, D., Croci, L., Cozzi, L., Ciccaglioni, G., and Palleshi, G.: A bienzyme electrochemical probe for flow injection analysis of okadaic acid based on protein phosphatase-2a inhibition: An optimization study, Anal. Biochem., 385, 50-56, 2009.

Wang, J.: Electrochemical nucleic acid biosensors, Anal. Chim. Acta, 469, 63-71, 2002.

Wilson, R., Ducamp, J.-J., Rees, W., Culik, B., and Niekamp, K.: Estimation of location: Global coverage using light intensity., in: Wildlife telemetry, edited by: Priede, I. G. and Swift, S., Ellis Horwood, New York, 131-134, 1992.

Wilson, R. P., Steinfurth, A., Ropert-Coudert, Y., Kato, A., and Kurita, M.: Lip-reading in remote subjects an attempt to quantify and separate ingestion, breathing and vocalisation in free-living animals using penguins as a model, Mar. Biol., 140, 17-27, 2002.

Zazoua, A., Hnaien, M., Cosnier, S., Jaffrezic-Renault, N., and Kherrat, R.: A new hrp/catalase biosensor based on microconductometric transduction for nitrite determination, Mater. Sci. Eng., 29, 1919-1922, 2009.

Zehr, J. P., Hewson, I., and Moisander, P.: Molecular biology techniques and applications for ocean sensing, Ocean Sci., 5, 101113, 2009, http://www.ocean-sci.net/5/101/2009/.

Zhang, H. and Davison, W.: Diffusional characteristics of hydrogels used in dgt and det techniques, Anal. Chim. Acta, 398, 329-340, 1999. 